\title{
CHARACTERISTICS OF RELATED INFECTIONS HEALTH CARE IN AN INTENSIVE CARE UNIT OF A HOSPITAL SCHOOL GOIÂNIA-GOIÁSCITY
}

\section{Keila Cardoso dos Santos*1, Nayanne Caroline de Jesus Carneiro², Fernanda Alves Ferreira Gonçalves $^{3}$, Carlos Roberto Caixeta ${ }^{4}$, Camila Lucas de Souza ${ }^{5}$, Marianna Laízedos Santos ${ }^{6}$, Bárbara Ribeiro Miquelin Bueno ${ }^{7}$ and Kaiomakx Renato Assunção Ribeiro ${ }^{8}$}

\author{
1.2Nurse. University Salgado Oliveira- Campus Goiânia \\ ${ }^{3}$ Nursing, PhD in Nursing (FEN / UFG) \\ ${ }^{4}$ Nursing, Master of Nursing, (HC-UFG) \\ ${ }^{5}$ Nurse, Master of Nursing (FEN/UFG)
}

${ }^{6}$ Nurse. Medical Student. Faculty of Medical Sciences of the Central Plateau (Brasília / DF)

${ }^{7}$ Nurse. Specialist in Intensive Care Unit. Master's Degree in Nursing (FEN / UFG)

${ }^{8}$ Nurse. Specialist in Intensive Care Unit. Instituto Hospital de Base do Distrito Federal- Brasilia-DF

\section{ARTICLE INFO}

\section{Article History:}

Received $27^{\text {th }}$ August, 2019

Received in revised form

$29^{\text {th }}$ September, 2019

Accepted $19^{\text {th }}$ October, 2019

Published online $30^{\text {th }}$ November, 2019

\section{Key Words:}

Microorganism, Nosocomialinfection, Intensive care unit, Topography.

*Corresponding author:

Kleyber Dantas Torres de Araújo

\begin{abstract}
Objective: To describe the types of HAI in a public intensive care unit in the city of Goiânia. Method: a descriptive cross-sectional study conducted in an Intensive Care Unit between March and August 2012. A structured questionnaire was used, involving demographic data, hospitalization, risk factors and comorbidities. Results: 38 infections were identified in 26 patients. The HAI rate was $13 \%$, pneumonia had the highest incidence $63 \%$, followed by bloodstream infection with $13 \%$, and surgical site $10 \%$. Regarding the procedures, $92 \%$ of the patients were exposed to bladder catheterization, $65 \%$ used invasive mechanical ventilation and $61 \%$ underwent central venous catheterization. Pseudomonas aeruginosa was the most isolated microorganism, with an incidence of $29 \%$, followed by Acinetobacterbaumannii, $25.8 \%$, and Candida sp. $11 \%$. Conclusion: Among all HAI, there was a predominance of mechanical ventilation-associated pneumonia (VAP), although bladder catheterization was the most common invasive procedure. It is believed that continuing education with all ICU staff combined with daily auditing can improve the results obtained.
\end{abstract}

Copyright (C) 2019, Keila Cardoso dos Santos et al. This is an open access article distributed under the Creative Commons Attribution License, which permits unrestricted use, distribution, and reproduction in any medium, provided the original work is properly cited.

Citation: Keila Cardoso dos Santos1, Nayanne Caroline de Jesus Carneiro, Fernanda Alves Ferreira Gonçalves et al. 2019. “Characteristics of related infections health care in an intensive care unit of a hospital school goiânia-goiás city”, International Journal of Development Research, 09, (11), 3157031573 .

\section{INTRODUCTION}

Health care associatedinfections (HAIs) are defined as those acquired after admission of the patient and manifested during hospitalization or after discharge-related hospitalization or hospital procedures (Menezes et al., 2007, STANDARD et al ., 2012), which are still present adverse events in health services (ANVISA, 2017). The patient houses the main triggering microorganisms of HAI. Several factors can contribute to the acquisition of these infections, such as underlying disease, malnutrition, immune deficiency, use of immunosuppressive drugs, extremes of age, invasive procedures, use of antimicrobial and non health staff accession measures infection control (ALP; Damani, 2015, Pereira et al, 2012, LEISER;. TOGNIM; BEDENDO, 2012). The IRAS directly influence the hospital stay, morbidity and mortality and mortality, consumption of antibiotics, laboratory tests and spent the isolation of patients, reflecting significantly in hospital costs (ANDRADE; LEOPOLDO; HAAS, 2012, ANVISA, 2017). The occurrence of IRAS is high in Intensive Care Units (ICU) compared to other sectors of the hospital, and the risk of death in these patients is three times higher. In this unit include the occurrence of infections related to respiratory tract, urinary tract, bloodstream and surgical site. Approximately 5 to $15 \%$ of hospitalized patients and 25 to $35 \%$ of hospitalized patients in the ICU acquired infections, 
and these are the fourth leading cause of death in Brazil (LEISER; TOGNIM; BEDENDO, 2012). About $70 \%$ of HAI are controllable and $30 \%$ are preventable. Among the preventive measures stand out hand hygiene (HM), the use of personal protective equipment (PPE), and adherence to aseptic measures. It is noteworthy that the adherence to standard precautions, use of appropriate equipment, staff training, rational use of antimicrobial and implementation of infection control measures are factors that interfere directly in lowering the levels of HAI (ALP; Damani, 2015 LISBON, NAGEL, 2011, Pereira et al, 2005, MOURA, 2007). Among these measures is the HM alone the simplest action is important in the prevention and control of HAI. They should wash their hands all professionals of health services, which maintains direct or indirect contact with patients, family members, caregivers and visitors before and after contact with the patient in health services (ANVISA, 2012). Study the types of IRAS contributes to improving the quality of care,considering that the health team knowledge can influence in reducing the incidence of these infections. Thus, this study may sensitize the health staff and to encourage adherence in the face of actions related to the prevention and control of these infections. Therefore, constitute the following objectives: describe the types of IRAS in a public ICU in Goiânia, relating the procedures on the type of infection and list the microorganisms involved.

\section{MATERIALS AND METHODS}

This is a descriptive, prospective, quantitative study conducted in an adult ICU of a public hospital and school in the city of Goiânia, state of Goiás. The data were collected from March 2012 to August 2012 during every day of the week through interviews using a structured questionnaire involving demographics data partners, hospitalization, risk factors and comorbidities. This collection included the participation of eight previously trained interviewers and the questionnaire was completed through the records and active chips of Hospital InfectionControl Service data. The study population included all patients admitted to the ICU during the period of data collection, totaling 274 patients. Of these 68 patients were lost, resulting in a sample of 206 patients in this sample were affected by IRAS 26 patients who were included in this study. All participants agreed to join the study by signing the Informed Consent Form (ICF). In the case of the patient's inability to sign the Informed Consent (sedation, coma) was approached family, prioritizing who live with the patient. The study was conducted according to the rules of Resolution 466/12 of the National Health Council, after approval by the Research Ethics Committee of the Hospital das Clinicas, Federal University of Goiás (CEP / HC / UFG),Under Protocol. 078/2011. For data analysis we used the Statistical Package for Social Sciences (SPSS) version 11.5 for Windows and presented in tables.

\section{RESULTS}

Table 1 shows the demographic data of patients admitted to the ICU and had IRAS. The data relating to the stay rate of patients who acquired IRAS during hospitalization in a hospital school in the city of Goiânia, 2012 are presented in Table 2. In relation to urethral catheterization $92 \%$ of patients were exposed to this procedure, $65 \%$ used mechanical ventilation and $61 \%$ were subjected to central venouscatheterization. The HAI $(\mathrm{n}=38)$ were identified in 26 patients during the study period. It is worth noting that despite the bladder catheterization have been the more invasive procedure performed, the most frequent IRAS that UTI was the respiratory tract $(63 \%)$ (Table 5).

Table 1. Sociodemographic characteristics of patients who acquired IRAS during hospitalization in the intensive care unit of a teaching hospital in the city of Goiânia / GO, 2012

\begin{tabular}{lll}
\hline Sociodemographic characteristics & $\mathrm{n}$ & $(\%)$ \\
\hline Sex & & \\
Feminine & 14 & 54 \\
Male & 12 & 46 \\
Total & 26 & 100 \\
Age & & \\
$18-29$ & 02 & 8 \\
$30-59$ & 09 & 35 \\
$>60$ & 15 & 57 \\
Breed & & \\
White & 20 & 77 \\
black & 05 & 19 \\
Others & 01 & 4 \\
Higher education & & \\
Fundamental & 12 & 46 \\
Illiterate & 08 & 31 \\
Medium & 05 & 19 \\
Higher & 01 & 4 \\
\hline
\end{tabular}

Table 2. Stay rate and type of discharge of patients who acquired IRAS during hospitalization in the intensive care unit of a teaching hospital in the city of Goiânia / GO, 2012

\begin{tabular}{lll}
\hline Permanence Rate (Days) & $\mathrm{N}$ & $\mathbf{( \% )}$ \\
\hline $01-10$ & 13 & 50 \\
11 to 20 & 07 & 27 \\
21 to 30 & 02 & 8 \\
Over 31 & 04 & 15 \\
Total & 26 & 100 \\
Kind of high & & \\
Death & 15 & 58 \\
Transfer & 11 & 42 \\
*Download: intrahospitable & &
\end{tabular}

Table 3. Procedures performed in patients with acquired IRAS during hospitalization in the intensive care unit of a teaching hospital in the city of Goiânia / GO, 2012

\begin{tabular}{lcc}
\hline Invasive Procedures & $\mathrm{N}$ & $\mathbf{( \% )}$ \\
\hline Bladder catheterization & 24 & 25.5 \\
Intubation / tracheostomy & 17 & 18.1 \\
Central VenousCatheterization & 16 & 17.0 \\
Arterycatheterization & 14 & 14.9 \\
Installation probes & 13 & 13.9 \\
Drainage & 06 & 6.4 \\
Peripherallyinserted central catheter & 04 & 4.2 \\
Total & 94 & 100 \\
\hline
\end{tabular}

Table 4. Topography infection rate of patients who acquired IRAS in the Intensive Care Unit of a teaching hospital in the city of Goiânia / GO, 2012

\begin{tabular}{lll}
\hline Topography & $\mathrm{n}$ & $(\%)$ \\
\hline Respiratory tract (EPI + PNM) & 24 & 63 \\
Blood flow & 5 & 13 \\
surgical site & 4 & 10 \\
urinary tract & 3 & 8 \\
Skin and soft tissue & 1 & 3 \\
Others & 1 & 3 \\
Total & 38 & 100 \\
\hline
\end{tabular}

It notes that, among the $63 \%$ of respiratory tract infections, $87 \%$ were associated with mechanical ventilation. 11 patients 
were identified with bacteria admission, and VRE (vancomycin-resistant enterococcus), Escherichia coli, Staphylococcus aureus, MRSA (methicillin-resistant staphylococcus aureus), Streptophommas, ESBL (extended beta-lactamaseexpectro). Table 6 are distributed agents that were isolated from patients who acquired IRAS.

Table 5. Distribution of microorganisms in patients who acquired IRAS in the Intensive Care Unit of a teaching hospital in the city of Goiânia / GO, 2012

\begin{tabular}{lcc}
\hline single agents & $\mathrm{n}$ & $\mathbf{( \% )}$ \\
\hline Pseudomonasaeruginosa & 09 & 32 \\
Acinetobacterbaumannii & 08 & 28 \\
Candidasp & 04 & 14 \\
Klebsiellapneumoniae & 03 & 10 \\
Escherichia coli & 01 & 4 \\
Stenotrophomonasmaltophilia & 01 & 4 \\
Citrobacterfreudii & 01 & 4 \\
Staphylococcuspneumoniae & 01 & 4 \\
Total & 28 & 100 \\
\hline
\end{tabular}

Compared to HAI acquired during hospitalization in the ICU was found that the majority $(96 \%)$ is associated with gramnegative bacteria (Pseudomonas aeruginosa, Acinetobacter baumannii, Klebsiella pneumoniae, Escherichia coli, Stenotrophomonas maltophilia. Citrobacter freudii), the fungus (Candida sp.) and only one (4\%) gram-positive (Staphylococcuspneumoniae). It is worth noting that $71 \%$ of HAI were diagnosed by culture and $29 \%$ through clinical diagnosis using the criteria of ANVISA (2017). A higher incidence of Pseudomonas aeruginosa isolated cultures in 9 (32\%), followed by Acinetobacter baumannii (28\%) and Candida sp. (14\%).

\section{DISCUSSION}

The study population totaled 206 patients, 26 were affected by IRAS. The IRAS rate (13\%) found in the study was similar to my obtained a study from June 2003 to July 2004 in the state of Paraná, which found a rate of $15.95 \%$. Unlike what was found in the period from February to July 2006 in São Paulo, where it obtained a rate of $66.2 \%$ (LEISER; TOGNIM; BEDENDO, 2007 LIMA; ANDRADE; HAAS, 2007). People affected by IRAS in this study, 54\% were female, different from the rate found in a study conducted in the ICU of the Hospital of Ribeirão Preto, where there was a predominance of males (59\%) (LIMA; ANDRADE; HAAS, 2007). Out of 83 patients who had length of stay in ICU top to five days, 26 (31\%) developed IRAS, showing that prolonged hospitalization constitute a risk factor for acquiring infections (OLIVEIRA; Kovner; SILVA, 2010b). It was also found that the mortality rate in patients who acquired IRAS corresponded to $58 \%$, similar to the rate found in a study conducted in the ICU of a teaching hospital of Ribeirão Preto, where the death rate was $50 \%$ while in patients IRAS without the rate was $11 \%$ (ANDRADE; LEOPOLDO; HAAS, 2006). The severity of the underlying disease, extremes of age, nutritional status, invasive procedures increase the risk for development of HAI. In addition, ICU patients are most likely taking risk 5-10 times higher for its acquisition. Most HAI develop as complications in critically ill patients as a result of prolonged hospitalization and exposure to invasive procedures (Oliveira et al, 2010a, LIMA; Andrade; HAAS 2007). All patients affected by IRAS used at least one invasive procedure. 94 procedures performed were recorded in 26 patients, presenting a utilization rate of 3.6 per patient procedures.

Since $92 \%$ of the patients used indwelling catheter $65 \%$ were intubated or tracheostomized $61 \%$ used central venous catheter $54 \%$ used arterial catheter, showing high utilization of these procedures in the ICU (AX; CARVALHO, Oliveira, 2011, Oliveira et al ., 2010b). The main respiratory tract agents were Acinetobacter baumannii (29\%), Pseudomonas aeruginosa $(21 \%)$ and Klebsiella pneumoniae $(8 \%)$, similar to that found in a study conducted in an ICU of a teaching hospital in Londrina, which found that Acinetobacter baumannii was the highest incidence agent (25\%). Acinetobacter baumannii has been considered a major agent in the ICU, the high level of resistance to carbapenems and ease of adapting to the hospital for long periods (RAM; Saridakis, 2008). Concerning topography, the respiratory tract infection is the most frequent infection came to represent $63 \%$ of HAI, then the bloodstream $13 \%$ of the surgical site $(10 \%)$ and urinary tract $(8 \%)$. With regard to the procedures used $61 \%$ of patients central venous catheter and $13 \%$ developed bloodstream infection, Pseudomonas aeruginosa being responsible for $60 \%$ of HAI. The prevalence of gram-negative agent was also found in a study conducted in seven hospitals ICUs in the Federal District (Mesiano; Merchan-Hamann, 2007). In this study, the surgical site infection (SSI) is the third among the main IRAS $10 \%$ of infections occurred where three were diagnosed clinically and by laboratory culture (Escherichia coli). The rate of this infection was small considering that the study site are patients in the immediate postoperative period of several specialties. Another significant finding is related to the presence of Candida sp., As the only microorganism isolated, accounting for $100 \%$ of urinary tract infections (UTI) as different from that found in a study conducted in a university hospital in Fortaleza, where the main microorganisms were Klebsiella pneumoniae (25.2\%), Escherichia coli (20.6\%) and Candida sp. (11.6\%) (Nogueira et al, 2009). Candida sp. belongs to microflora of the gastrointestinal tract and hands, can not be said that the lack of HM may be the main factor of the occurrence of this infection in the study unit, however this result demonstrates the importance of $\mathrm{HM}$ and antisepsis properly prior to Catheterization (Nogueira et al, 2009). The ITU is one of the most common infections, and approximately $70 \%$ to $80 \%$ of cases occur in patients undergoing bladder catheterization (Moura et al. 2007) 8. In this study, 92\% of patients were exposed to this procedure, but ITU accounted for $8 \%$ of HAI.

\section{Conclusion}

This study found that among all IRAS was the prevalence of pneumonia associated with mechanical ventilation (PAV) despite the bladder catheterization have been the most performed invasive procedure. The bloodstream infections, surgical site and urinary tract infections occurred less frequently. Among the microorganisms prevalent there are the gram-negative bacteria (Pseudomonas aeruginosa, Acinetobacter baumannii, Klebsiella pneumoniae, Escherichia coli, Stenotrophomonas maltophilia. Citrobacterfreudii). It is therefore recommended, the need for preventive education programs in order to reduce HAIs. It is believed that continuing education with all the ICU staff coupled with the daily audit can improve the results. 


\section{REFERENCES}

ALP, Emine, Damani, Nizam. Healthcare-associated infections in Intensive Care Units: epidemiology and infection control in low-to-middle income countries. The Journal of Infection in Developing Countries, North America, v.9, n.910, p.1040-1045 oct. 2015. Available at: $<$ http://www.jidc.org/index.php/journal/article/view/2651 7477/1390>. Accessed on: 23 Jan. 2017.

ANDRADE, Denise; LEOPOLDO, Vanessa Cristina; HAAS, Vanderlei José.Occurrence of multi-resistant bacteria in a intensive care unit of Brazilian emergency hospital. RBTI, v.18, n.1, p.27-32, Jan / Mar. 2006. Available at:http://www.scielo.br/scielo.php?script=sci_arttext\&pid $=$ S0103-507X2006000100006. Accessed on: 23 Mar. 2012.

ANVISA. National Health Surveillance Agency. Patient Safety - Hand hygiene, p.1-100, 2012. Available at:http://www.anvisa.gov.br/servicosaude/manuais/pacient e_hig_maos.pdf. Accessed on: 14 May 2012..

ANVISA. National Health Surveillance Agency. Prevention measures

Carneiro, Marcelo; Saridakis, Halha Ostrensky. Ventilatorassociated pneumonia Acinetobacter baumannii carbapenem resistant. Rev Panam Infectol, v. 10, No.2, p.28-33, April / June. 2008. Available at: http://www. revistaapi.com/wp-content/uploads/2014/02/ mat0511.pdf. Accessed on: 16 Oct 2012.

infection related to health care. Brasilia (Brazil): Ministry of Health; 2017. p. 201. Available at: http://portal.anvisa. gov.br/documents/33852/271855/Medidas + de+Preven $\% \mathrm{C}$ $3 \% \mathrm{~A} 7 \% \mathrm{C} 3 \% \mathrm{~A} 3 \mathrm{o}+\mathrm{de}+\mathrm{Infec} \% \mathrm{C} 3 \% \mathrm{~A} 7 \% \mathrm{C} 3 \% \mathrm{~A} 3 \mathrm{o}+$ Relacio nada $+\% \mathrm{C} 3 \% \mathrm{~A} 0+$ Assist AAncia $\%$ C3\% +\% C3\% A0 + $\mathrm{Sa} \% \quad$ C3\% Baden / 6b16dab3-6d0c-4399-9d84141d2e81c809. Accessed on 01 Apr 2017.

LEISER, Jacir Julius; TOGNIM, Maria Cristina Bronharo; BEDENDO, John. Nosocomial infections in the intensive care unit of a teaching hospital in northern Paraná. Cienc Cuid Health, v.6, n.2, p.181-186, Apr / Jun. 2007. Available at: http://www.periodicos.uem.br/ojs/index.php/ CiencCuidSaude/article/view/4149. Accessed on: 23 Mar. 2012.

LIMA, Mery Ellen; ANDRADE, Denise; HAAS, Vanderlei José. Prospective assessment of the occurrence of infection in critically ill patients in intensive care unit. RBTI, v.19, n.3, p.342-347, Jul / Sep. 2007. Available at:http://www.scielo.br/pdf/rbti/v19n3/v19n3a13. Accessed on: 25 Sep 2012.

Lisbon, Silva; NAGEL, Fabiano. Infection by multidrugresistant pathogens in ICU: escape? RBTI, v.23, n.2, p.120-124, 2011. Available at: http://www.scielo.br/pdf/ rbti/v23n2/a03v23n2.pdf. Accessed on: 27 Mar. 2012.
MACHADO, Miranda Richardson; CARVALHO, Vilma Dacle; OLIVEIRA, Adriana Cristina. epidemiological aspects of hospital infections in the intensive care unit of a university hospital. R. The Enferm Cent Min, v. 1, n.1, p.9-16, Jan / Marc. 2011. Available at: http://www.seer. ufsj.edu.br/index.php/recom/article/view/9. Accessed on: 26 Sep 2012.

Menezes, Everardo Albuquerque. et al. Frequency and percentage of susceptibility of bacteria isolated in patients treated in the intensive care unit of the General Hospital of Fortaleza. Bras Med Pathol Lab, V.43, n.3, p.149-155, June 2007. Available at:. :http:/www.scielo.br/ $\mathrm{pdf} / \mathrm{jbpml} / \mathrm{v} 43 \mathrm{n} 3 / \mathrm{a} 03 \mathrm{v} 43 \mathrm{n} 3 . \mathrm{pdf}$. Accessed on: 16 Oct 2012 ..

Mesiano, Eni Rosa Aires Borba; Merchan-Hamann, Edgar. Bloodstream infections in patients with central venous catheters in intensive care units. Rev. Latino-Am. Nursing, n.3, p.15, May / June. 2007. Available at: http://www. scielo.br/pdf/rlae/v15n3/pt_v15n3a14.pdf. Accessed on: 16 Oct 2012 ..

MOURA, Maria Eliete Baptist. et al. Nosocomial infection: study of prevalence at a public teaching hospital. REBEn, Brasília, v. 60. no.4, p.416-21, Jul / Aug. 2007. Available at:http://www.scielo.br/pdf/reben/v60n4/a11.pdf. Accessed on: 23 Mar. 2012.

OLIVEIRA, Adriana Cristina et al. bacterial resistance and mortality in a intensive care unit. Rev. Latino-Am. Nursing, v.18, n.6, p. 01-10, Nov / Dec. 2010a. Available in:http://www.scielo.br/pdf/rlae/v18n6/pt_16.pdf. Accessed on: 03 Apr 2012.

OLIVEIRA, Adriana Cristina; Tassone Christine Kovner; SILVA, Rafael Souza. nosocomial infection in intensive care unit of a Brazilian university hospital. Rev. LatinoAm. Nursing, v.18, n.2, p. 97-104, Mar / Apr. 2010 b. Available in:http://www.scielo.br/pdf/rlae/v18n2/pt_14.pdf. Accessed on: 23 Mar. 2012.

Pereira, Melcha Severino et al. Hospital infection and its implications for the care of nursing. Text Enferm context. v.14, n.2, p.250-257, Apr / Jun. 2005. Available at:http://www.scielo.br/pdf/tce/v14n2/a13v14n2.pdf. Accessed on: 13 Apr 2012.

STANDARD, Manuella the Cross. et al. The prevalence of nosocomial infections in intensive care unit. Rev. Bras Clin Med, Vol. 8, no.2, p. 125-128, 2010. Available at:http://files.bvs.br/upload/S/1679-

1010/2010/v8n2/a007.pdf. Accessed on: 23 Mar. 2012.

WALNUT, Paula Sacha Fleet. et al. Profile of hospital infection in a university hospital. Rev. Enferm. UERJ, Rio de Janeiro, v.17, n.1, p.96-101, 2009. Available at:http://files.bvs.br/upload/S/0104-3552/2009/v17n1/ a017.pdf. Accessed on: 27 Mar. 2012. 